\title{
The Effect of Different Irrigation Levels in Cowpea Production in the Mid-Northern Region of Tocantins-Brazil
}

\author{
Francisco Maurício Alves Francelino1,2, Fábio Cunha Coelho', \\ Carmen Maria Coimbra Manhães ${ }^{2}$, Danilo Gomes de Oliveira ${ }^{3}$, \\ Levi Rodrigues Neto ${ }^{4}$, Mírian Peixoto Soares da Silva²
}

${ }^{1}$ State University of North Fluminense-Darcy Ribeiro-UENF, Campos, Brazil

${ }^{2}$ Federal Institute of Education, Science and Technology of Tocantins-IFTO, Pedro Afonso, Brazil

${ }^{3}$ Federal Institute of Education, Science and Technology Goiano-IFGOIANO, Posses, Brazil

${ }^{4}$ Federal Institute of Education, Science and Technology of Tocantins-IFTO, Colinas do Tocantins, Brazil

Email: francisco.francelino@ifto.edu.br, fabiocoelhouenf@gmail.com, carmen.manhaes@ifto.edu.br, levi.neto@ifto.edu.br,

mirian.silva@ifto.edu.br

How to cite this paper: Francelino, F.M.A., Coelho, F.C., Manhães, C.M.C., de Oliveira, D.G., Neto, L.R. and da Silva, M.P.S. (2018) The Effect of Different Irrigation Levels in Cowpea Production in the Mid-Northern Region of Tocantins-Brazil. American Journal of Climate Change, 7, 548-557.

https://doi.org/10.4236/ajcc.2018.74033

Received: June 20, 2018

Accepted: October 26, 2018

Published: October 29, 2018

Copyright (C) 2018 by authors and Scientific Research Publishing Inc. This work is licensed under the Creative Commons Attribution International License (CC BY 4.0).

http://creativecommons.org/licenses/by/4.0/

Open Access

\begin{abstract}
The objective of this study was to evaluate the effects of the application of irrigation levels in the productivity and water use efficiency, in the soil and climatic conditions of the municipality of Colinas do Tocantins, located in the Mid-Northern region of the State of Tocantins. The cowpea cultivation system was submitted to the application of five irrigation blades, based on ET0-Reference Evapotranspiration: Blade $0 \%$ of ET0, Blade 50\% of ET0, Blade $75 \%$ of ET0, Blade $100 \%$ of ET0 and Blade $125 \%$ of ET0 (B0, B50, B75, $\mathrm{B} 100$ and $\mathrm{B} 125 \%$ of $\mathrm{ET}_{0}$ ). The descriptive statistics were used to analyze the data, applying the $95 \%$ confidence interval to discriminate the differences between the treatments, since the replicates were constituted of 100 plants harvested at random within the plot for each treatment and no design method was performed. A significant effect of the different levels was found on all evaluated components, with the exception of the length of the pod, which did not differ in the irrigation levels. The increase in irrigation contributed to the increase of the results of the components that compete directly for higher productivity, such as number of pods per plant, weight of pods and number of seeds per pod. In these results, it was found that higher irrigation levels confer higher yields. Water-use efficiency-WUE behaved as per productivity trend, that is, it decreased with the reduction of irrigation levels.
\end{abstract}

\section{Keywords}

Vigna unguiculata (L.), Productivity, Water Efficiency 


\section{Introduction}

The cultivation of cowpeas plays an important role in agricultural development, both economically and in terms of nutrition. It performs socioeconomic functions, especially for low income rural populations, meeting their nutritional needs.

In addition to the use for consumption in nature, especially in the form of dry or green seeds, cowpeas are also used as fodder, hay, silage, feed, green manuring and soil protection [1].

According to [2], the cowpea is considered a plant species with great genetic variability, and can be used for different purposes and in different cultivation modes. In addition, it has great adaptability to different environmental conditions, being of great nutritional value because it contains the amino acids considered essential to humans in its composition.

In the first Brazilian harvest, the cowpea is the third most cultivated crop in the country. Its production is concentrated in the Northeast, more particularly in Piauí and Bahia. The estimate for Brazil in the 2017/2018 harvest is a reduction of area from 1409.30 thousand ha to 1402.60 thousand ha $(0.5 \%)$ and yield from $506 \mathrm{~kg} \cdot \mathrm{ha}^{-1}$ to $470 \mathrm{~kg} \cdot \mathrm{ha}^{-1}(7.1 \%)$ in the face of unfavorable climatic conditions in this harvest. With this climate standing, production should be $7.6 \%$ lower, reaching 659 thousand tons. And the estimate for the state of Tocantins in the 2017/2018 harvest is for the maintenance of an area of 41.1 thousand ha and a yield reduction from $1630 \mathrm{~kg} \cdot \mathrm{ha}^{-1}$ to $1274 \mathrm{~kg} / \mathrm{ha}(21.9 \%)$, and also a reduction in the production estimate, from 67 thousand $\mathrm{t}$ to 52.4 thousand $\mathrm{t}$ (21.8\%) [3].

The average Brazilian yield in the 2016/2017 harvest was $506 \mathrm{~kg} \cdot \mathrm{ha}^{-1}$ and in the State of Tocantins it was of $1630 \mathrm{~kg} \cdot \mathrm{ha}^{-1}$. It is worth mentioning that in this harvest Tocantins was the Brazilian state that presented the highest yield. The national production was 713 thousand tons and Tocantins' production was 67 thousand tons, corresponding to $9.4 \%$ of the national production [3].

To meet crop water needs in times when there is no rainfall, farmers generally make use of irrigation to meet the full watering demand of plants and maximize yield [4].

Currently, researches carried out by public institutions, such as Embrapa, have allowed the cultivation of cowpea cultivars, which have highly favorable agronomic characteristics to the production of dry and green seeds. These cultivars usually have a high response to irrigation [5].

However, there is still little information on the management of different irrigation levels in the cowpea culture in Brazil and particularly in the state of Tocantins, this data is scarce.

In this sense, the objective of this research was to evaluate the effects of the application of irrigation levels in productivity and water use efficiency in the soil and climatic conditions of the municipality of Colinas do Tocantins, located in the Mid-Northern region of the State of Tocantins. 


\section{Material and Methods}

The experiment was conducted in the experimental area of Instituto Federal de Educação, Ciência e Tecnologia do Tocantins-IFTO Campus Colinas do Tocantins-TO (Federal Institute of Education, Science and Technology of Tocantins-IFTO Colinas do Tocantins Campus-TO), at coordinates $8^{\circ} 3^{\prime} \mathrm{S}$ and $48^{\circ} 28^{\prime} \mathrm{W}$. The local climate is characterized, according to the Köppen and Geiger classification, as Aw (Tropical Climate with an average temperature in Colinas do Tocantins of $26.2^{\circ} \mathrm{C}$ and average annual rainfall of $1847 \mathrm{~mm}$, with a rainy summer and dry winter). The soil of the experimental area is characterized as Red-Yellow Latosol [6], and light-sandy Texture Class [7].

The preparation of the soil consisted of two harrowing sessions, one at the moment of the application of limestone for its incorporation and the other 90 days later for leveling and elimination of weeds in the place. Basic fertilization was performed based on the interpretation of the soil analysis results. The detail of the irrigation system and its distribution in the field can be observed in Figure 1, where we can see the drippers' tubes and the respective areas moistened.

The cultivar Sempre Verde was used, the irrigation system adopted was drip irrigation with emitters spaced at $0.25 \mathrm{~m}$. Sowing occurred in November 23, 2016.

The cowpea cultivation system was implanted at a spacing of $0.5 \mathrm{~m}$ between rows and $0.5 \mathrm{~m}$ plants, and two plants per pit with a mean density of 80,000 plants.ha ${ }^{-1}$. The cultivation system was submitted to irrigation levels corresponding to $100 \%$ of the evapotranspiration reference (ET0) from emergency until 15 days after sowing (end of the initial stage of the cowpea). From then on, irrigation control was initiated through the application of treatments that consisted of five different irrigation levels. The levels were based on the values related to Evapotranspiration Reference-ET0, namely: Blade $0(\mathrm{~B} 0)=0 \%$ of ET0; Blade $50(\mathrm{~B} 50)=50 \%$ of ET0; Blade $75(\mathrm{~B} 75)=75 \%$ of ET0; Blade $100(\mathrm{~B} 100)=100 \%$ of ET0 and Blade 125 (B125) = 125\% of ET0.

The experimental plot consisted of six lines of $8.0 \mathrm{~m}$ in length each, spaced by $0.5 \mathrm{~m}$, totaling an area of $24.0 \mathrm{~m}^{2}$, being considered for evaluation purposes the

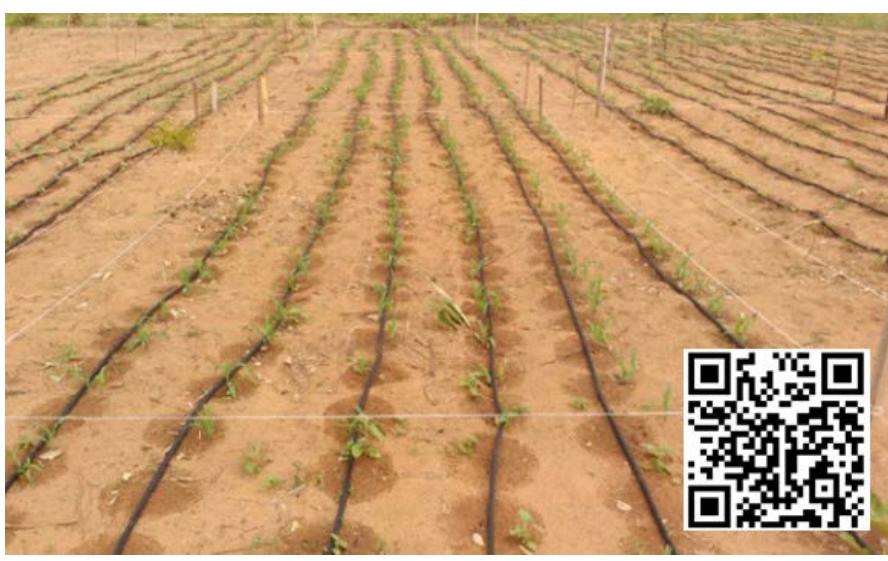

Figure 1. IFTO Campus Colinas do Tocantins. 
four central lines with a useful area of $14.0 \mathrm{~m}^{2}$, excluding $0.5 \mathrm{~m}$ of border at the ends of the plot. The stand of plants within each plot was 112 plants, and for the purpose of evaluations, as sample unit were used the bean-cowpea plants. A total of 100 plants were taken at random within each useful plot for each treatment, each of which corresponds to one replicate. All production components were evaluated in each of the replicates. Finally, descriptive statistics (random sampling method) were used to analyze the data, applying the $95 \%$ confidence interval to discriminate the differences between the treatments.

\subsection{Production Components Evaluated}

The procedures adopted for analysis of yield of the plants comprised the collection of the pods of all the plants of the area for each treatment. The Plant Height (PH) component was measured in the field and after this measurement, the pods were harvested and packed in paper bags and taken to the oven for drying at $65^{\circ} \mathrm{C}$ for 48 hours, for further analysis of the production.

The production components evaluated after drying were: number of pods per plant (NPP), pod length (PL) and number of seeds per pod (NSP).

\subsection{Water-Use Efficiency and Yield}

The water-use efficiency (WUE) $\left(\mathrm{kg} \cdot \mathrm{ha}^{-1} \cdot \mathrm{mm}^{-1}\right)$ was calculated by correlating seed yield (Seey) and applied and the total water depth, using the following expression adapted from [8]:

$$
W U E=\frac{\text { Seey }}{I L}
$$

where:

$W U E=$ water-use efficiency $\left(\mathrm{kg} \cdot \mathrm{ha}^{-1} \cdot \mathrm{mm}^{-1}\right)$

Seey $=$ seed yield $\left.(\mathrm{kg} \cdot \mathrm{ha})^{-1}\right)$ and $\mathrm{IL}=$ accumulated irrigation level $(\mathrm{mm})$.

\section{Results and Discussions}

The results of the confidence interval constructed by the " $\mathrm{t}$ " statistic is $5 \%$ probability for the components of production: plant height $(\mathrm{PH})$, number of pods per plant (NPP), pod weight (PW), pod length (PL) and number of seeds per pod (NSP) in the exclusive cultivation systems of cowpeas-ECC and in the consortium system-SCMF under the effect of different irrigation levels are presented in Table 1.

A significant effect was shown on all evaluated components, except in pod length (Table 1).

The $(\mathrm{PH})$ component was favored by the irrigation levels of $50 \%$ and $125 \%$ respectively, and therefore differed from the others at $5 \%$ of probability, while the levels $0 \%$ and $75 \%$ presented the least effect for this component and did not impose difference between them at 5\% probability. [9] studying the physiological characteristics and production components of cowpeas under different irrigation levels found lower results for plant height. The values observed in the 
Table 1. Cowpea production components: plant height $(\mathrm{PH})$, number of pods per plant (NPP), pod weight (PW), pod length (PL) and number of seeds per pod (NSP) submitted to different irrigation levels. Colinas do Tocantins, TO, 2016/2017.

\begin{tabular}{cccccc}
\hline Treat. & \multicolumn{5}{c}{ Production Components of Cowpeas } \\
\hline B0\% & PH $(\mathrm{m})$ & NPP & PW (g) & PL (m) & NSP \\
\hline B50\% & $0.55 \mathrm{C}$ & $4.6 \mathrm{D}$ & $6.6 \mathrm{D}$ & $0.15 \mathrm{~A}$ & $7.63 \mathrm{D}$ \\
$\mathrm{B} 75 \%$ & $0.63 \mathrm{~A}$ & $6.27 \mathrm{~B}$ & $10.97 \mathrm{~B}$ & $0.15 \mathrm{~A}$ & $10.73 \mathrm{~B}$ \\
$\mathrm{~B} 100 \%$ & $0.53 \mathrm{C}$ & $5.31 \mathrm{C}$ & $9.24 \mathrm{C}$ & $0.15 \mathrm{~A}$ & $9.8 \mathrm{C}$ \\
$\mathrm{B} 125 \%$ & $0.59 \mathrm{~B}$ & $6.32 \mathrm{~B}$ & $11.68 \mathrm{~B}$ & $0.15 \mathrm{~A}$ & $11.23 \mathrm{~B}$ \\
\hline
\end{tabular}

${ }^{*}$ Means followed by different letters (column) differ from one another by the confidence interval constructed by the " $\mathrm{t}$ " statistic at $5 \%$ probability.

present research for plant height are in accordance with those desired for more technical crops.

According to [10], the demand for cultivars, with plant architecture that facilitates cultural practices and harvest, is very high. Cultivars with the most upright position have been one of the main demands of both rural entrepreneurs and family farmers.

The NPP production component, which has a direct relationship with productivity, showed a significant difference at $5 \%$ probability in ECC due to the irrigation levels, it was shown that the NPP increased with the increment of the irrigation levels reaching the point of optimal technical efficiency with 8 pods per plant, with the level of $125 \%$. This result shows that there is a positive relation between the amount of water applied and the production of pods per plant.

By analyzing each irrigation level individually and its effect on the cultivation system, the dependence of the water increment on pod production is even more evident, which can be easily observed in the difference in the number of pods between the levels, especially in the exclusive cowpea system in which the control treatment (B0\%), which did not receive irrigation water after the initial 15 days, had a reduction of approximately $57 \%$ in this component when compared to the highest irrigation level (B125\%).

These results corroborate with research conducted by [11], which evaluated the production components, productivity and efficiency of irrigation of cowpeas in the cerrado of Roraima, concluded that the number of pods per plant is directly affected by the increment of irrigation. Similarly, [5], evaluating the effect of the variation of soil water levels on the growth and production of cowpeas, pods and green seeds, verified that the number of pods per plant was influenced by the water levels, being more affected by water deficit.

The results found by [12], also corroborate with the values found in this study. These authors analyzed different levels of irrigation for the cowpea in Parnaíba-PI, verifying that the production component with the greatest positive variability in response to the increase in seed yield was the number of pods per 
plant.

[13] studying the productive performance of the maize-cowpea consortium and soil water availability, also observed a decreasing behavior in the cowpea production variables due to the total irrigation levels. The number of pods per plant (NPP) was the production component that presented the greatest positive variability in response to the increase of the irrigation level and with direct implication in the increase of seed yield.

Analyzing the (PW) component, there was a decreasing trend in this component due to the irrigation levels, showing that there was a significant difference at $5 \%$ probability for this cultivation system. The ECC presented a PW of $17.17 \mathrm{~g}$ and $6.6 \mathrm{~g}$ for the levels of B125\% and L0\%, respectively, with a difference of $61 \%$, in favor of the higher irrigation level.

These results corroborate with the results found by [13] [14], which obtained the highest value for this component achieved in the $125 \%$ level calculated by the Class A Tank (ECA) method. These authors also concluded that both water deficiency and excess water caused a reduction in the weight of the pods.

In regards to the length of pods, according to the data presented in Table 1, we can observe that there was no significant difference at $5 \%$ probability, in the levels applied in the ECC, so there was no effect of irrigation levels (Table 1).

These results were close to those found by [9], which found a value for pod length of $18.86 \mathrm{~cm}$ for the canapu cultivar. [15] found values of 19.7 to $22.6 \mathrm{~cm}$ for cowpeas. These authors affirm that a longer pod length allows a greater amount of locus, providing more seeds per pod, however, plants with short or intermediate size pods are preferable, because in the presence of irrigation, these may have greater contact with the humid soil, facilitating the attack of the pods and seeds by microorganisms, damaging the production and, consequently, the crop's productivity.

The number of seeds per pod-NSP is an important component of production, although it is more related to genetic heritability characteristic, being little influenced by the environment [16]. With the results presented in Table 1, it was found that there was a significant difference at $5 \%$ probability for this, under the effect of the different irrigation levels. It was also found that the increase of irrigation contributed significantly to the increase of NSP, where the highest amount was obtained by applying the highest irrigation level-B125\% within the ECC.

These results corroborate with those found by [13], who observed that this component of production had linear effect in response to the application of irrigation levels, where the highest values of NSP (14.3) were obtained with the highest irrigation level corresponding to $385.8 \mathrm{~mm}$. Also, the response curves of this component presented increasing linear behavior with the application of the irrigation levels.

The results of the confidence interval constructed by the " $\mathrm{t}$ " statistic is $5 \%$ probability for the quantities of water applied-AL, seed yield-SEEY and water-use efficiency-WUE are presented in Table 2. 
Table 2. Applied level (AL), Seed Yield (SEEY) and Water-use efficiency (WUE) of cowpea culture in exclusive cultivated, submitted to different irrigation slides, in the Municipality of Tocantins Hills-TO 2016/2017.

\begin{tabular}{cccc}
\hline Treat. & $\begin{array}{c}\mathrm{AL} \\
(\mathrm{mm})\end{array}$ & $\begin{array}{c}\text { SEEY } \\
\mathrm{Kg} / \mathrm{ha}\end{array}$ & $\begin{array}{c}\text { WUE } \\
\left(\mathrm{Kg} \cdot \mathrm{m}^{-3}\right)\end{array}$ \\
\hline $\mathrm{B} 0 \%$ & $383 \mathrm{D}$ & $464 \mathrm{C}$ & $12.11 \mathrm{~B}$ \\
$\mathrm{~B} 50 \%$ & $483 \mathrm{CD}$ & $864 \mathrm{~B}$ & $17.89 \mathrm{~A}$ \\
$\mathrm{~B} 75 \%$ & $583 \mathrm{BC}$ & $665.6 \mathrm{BC}$ & $11.42 \mathrm{~B}$ \\
$\mathrm{~B} 100 \%$ & $683 \mathrm{AB}$ & $908.8 \mathrm{~B}$ & $13.31 \mathrm{~B}$ \\
$\mathrm{~B} 125 \%$ & $783 \mathrm{Aa}$ & $1333.6 \mathrm{~A}$ & $17.03 \mathrm{~A}$ \\
\hline
\end{tabular}

${ }^{*}$ Means followed by different letters (column) differ from one another by the confidence interval constructed by the " $\mathrm{t}$ " statistic at $5 \%$ probability.

From the observation of the results presented in Table 2, it was found that there was a significant difference at $5 \%$ probability for the components $\mathrm{AL}$, SEEY and WUE.

During the experimental period a rainfall of $383 \mathrm{~mm}$ occurred, so the productive response was also influenced by the rain, in addition to the irrigation levels. In this sense, the $\mathrm{L} 0 \%$ level received $383 \mathrm{~mm}$ corresponding to rainwater. The irrigation levels of $50 \%, 75 \%, 100 \%$ and $125 \%$ of ETo, in addition to received rainwater, resulted in the following total irrigation levels plus precipitation: 483 $\mathrm{mm}$ (B50\%), $583 \mathrm{~mm}$ (B75\%), $683 \mathrm{~mm}$ (B100\%) and $783 \mathrm{~mm}$ (B125\%).

The analysis of the means by the confidence interval constructed by the " $\mathrm{t}$ " statistic at $5 \%$ of probability, was significant for the amount of water applied by each irrigation level.

The productivity of cowpeas was greatly affected by the application of the irrigation levels. According to the data in Table 2, it can be observed that there was a significant difference at $5 \%$ probability. The levels that provided the highest productivity of dry seeds-SEEY, were those of B125\% and B100\%, with $1333.6 \mathrm{~kg} \cdot \mathrm{ha}^{-1}$ and $908.0 \mathrm{~kg} \cdot \mathrm{ha}^{-1}$, respectively.

These values were below those found by [4], who obtained values of 2492.86 $\mathrm{kg} \cdot \mathrm{ha}^{-1}$ and $2937.36 \mathrm{~kg} \cdot \mathrm{ha}^{-1}$ of green cowpea beans for the varieties BRS Paraguaçu and BRS Guariba, with application of $423 \mathrm{~mm}$ and $354 \mathrm{~mm}$ of water respectively.

The differences observed are due to the fact that these authors have performed green bean analysis, which is notably heavier due to the higher moisture content in the green seeds. In addition, this difference can be associated to the cultivars used and to the diversity of the soil and climatic conditions of the sites where the studies were conducted.

However, the values of this research were very close to those found by [13], for yields of cowpea seeds in a single system. The authors above found values of $1599.03 \mathrm{~kg} \cdot \mathrm{ha}^{-1}$ and $470.78 \mathrm{~kg} \cdot \mathrm{ha}^{-1}$, with the application of irrigation levels of $390.1 \mathrm{~mm}$ and $259.1 \mathrm{~mm}$ respectively.

The results of this research corroborate with the data found by [17], which 
studied the productive response and water-use efficiency of cowpeas in exclusive and intercropping systems in the northeastern semi-arid region and obtained dry seed yield values in the exclusive cowpea system of $571.4 \mathrm{~kg} \cdot \mathrm{ha}^{-1}$ and 1320.7 $\mathrm{kg} \cdot \mathrm{ha}^{-1}$ corresponding to the irrigation levels of $\mathrm{B} 0 \%$ and $\mathrm{B} 125 \%$, respectively. The cowpea cultivation system, in B0\% we obtained productivity $18.8 \%$ lower, while in B125\% we outperformed the results by $0.97 \%$.

With regards to water-use efficiency (WUE), we can observe that there was a significant difference at $5 \%$ probability, indicating that some irrigation levels were more efficient.

Thus, it is worth mentioning that, although the $100 \%$ and $125 \%$ levels provided higher seed yields, the analysis of water-use efficiency shows that the B0\% of ETo, that is, the one which received only rainwater, was more efficient, with $16.13 \mathrm{~kg} \cdot \mathrm{m}^{-3}$ of applied water.

[17], also studying the WUE in the cowpea, found an inverse behavior to the different cultivation systems, where the decrease of the WUE in relation to the applied levels occurred in the cowpea cultivation system, presenting values of $27.7 \mathrm{~kg} \cdot \mathrm{m}^{-3}$ and $17.0 \mathrm{~kg} \cdot \mathrm{m}^{-3}$, for $\mathrm{B} 0 \%$ and $\mathrm{B} 125 \%$, respectively.

[11], studying the efficiency of irrigation on different bean cultivars in the cerrado of Roraima, found a reduction in the efficiency of water use with the increment of irrigation levels, independently of the cultivar, in which the higher efficiencies for BRS Guariba $\left(9.74 \mathrm{~kg} \cdot \mathrm{mm}^{-1}\right)$, BRS Novaera $\left(10.04 \mathrm{~kg} \cdot \mathrm{mm}^{-1}\right)$ and BRS Pajeú (13.94 $\left.\mathrm{kg} \cdot \mathrm{mm}^{-1}\right)$, were obtained with the $30 \%$ level of the ETo $(107.3$ $\mathrm{mm}$ ), with yields of $1190.67 \mathrm{~kg} \cdot \mathrm{ha}^{-1}$ with BRS Guariba, $1113.60 \mathrm{~kg} \cdot \mathrm{ha}^{-1}$ with BRS Novaera and $1545.7 \mathrm{~kg} \cdot \mathrm{ha}^{-1}$ with BRS Pajeú.

\section{Conclusions}

It can be inferred that all the production components evaluated in the research were affected by the irrigation levels, except the length of pod that did not differentiate between the levels. The increase in irrigation contributed to the increase of the results of components that compete directly for productivity, such as number of pods per plant, weight of pods and number of seeds per pod. In these results, it was found that higher irrigation levels confer higher yields.

The increase in irrigation contributed to the productivity of dry cowpea seeds, where B125\% conferred the best performance, which justifies the adoption of irrigation technologies, especially in dry periods.

WUE behaved with the same productivity trend, that is, it decreased with the reduction of the irrigation levels. It is worth mentioning that although $\mathrm{B} 100 \%$ in the cowpea cultivation system had higher productivity in relation to $\mathrm{B} 50 \%$, its efficiency was inferior to $\mathrm{B} 50 \%$.

\section{Conflicts of Interest}

The authors declare no conflicts of interest regarding the publication of this paper. 


\section{References}

[1] Rocha, M.M., Carvalho, K.J.M., Freire Filho, F.R., Lopes, A.C.A., Gomes, R.L. F., Sousa, I.S. (2009) Controle genético do comprimento do pedúnculo em feijão-caupi. Pesquisa Agropecuária Brasileira, 44, 270-275. https://doi.org/10.1590/S0100-204X2009000300008

[2] FreireFilho, F.R., Lima, J.A.A. and Ribeiro, V.Q. (2005) Feijão-caupi: Avanços Tecnológicos. Embrapa Informação Tecnológica Brasília, DF, 519 p: Il.

[3] CONAB-Companhia Nacional do Abastecimento (2018) Acompanhamento da safra brasileira de grãos. V. 5-SAFRA 2017/18, N. 4-Quarto levantamento JANEIRO 2018

[4] Ramos, H.M.M., Bastos, E.A., Andrade Jr., A.S. and Marouelli, W.A. (2012) Estratégias ótimas de irrigação do feijão-caupi para produção de grãos verdes. Pesquisa Agropecuária Brasileira, 47, 576-583. https://doi.org/10.1590/S0100-204X2012000400014

[5] Ramos, H.M.M., Bastos, E.A., Cardoso, M.J., Ribeiro, V.Q. and Nascimento, F.N. (2014) Produtividade de grãos verdes do feijão-caupi sob diferentes regimes hídricos. Engenharia Agrícola, 34, 683-694. https://doi.org/10.1590/S0100-69162014000400008

[6] EMBRAPA (2013) Sistema Brasileiro de Classificação de Solos. 3 ed. rev. ampl. EMBRAPA, Brasília, DF, 353 p: il.

[7] Manhães, C.M.C., Francelino, F.M.A. and Rodrigues Neto, L. (2016) Caracterização biológica dos solos do campus Colinas do Tocantins-TO. Jornada de iniciação científica e extensão do IFTO.

[8] Lacerda, C.F., Neves, A.L.R., Guimarães, F.V.V., Silva, F.L.B., Prisco, J.T. and Gheyi, H.R. (2009) Eficiência de utilização de água e nutrientes em plantas de feijão-de-corda irrigadas com água salina em diferentes estádios de desenvolvimento. Engenharia Agrícola, 29, 221-230. https://doi.org/10.1590/S0100-69162009000200005

[9] Gonçalves, I.S., Silva, R.R., Oliveira, G.M., Santiago, E.J.P. and Oliveira, V.E.A. (2017) Características fisiológicas e componentes de produção de feijão caupi sob diferentes lâminas de irrigação. Journal of Environmental Analysis and Progress, 2, 320-329. https://doi.org/10.24221/jeap.2.3.2017.1456.320-329

[10] Silva, C.A., Abreu, A.F.B. and Ramalho, M.A.P. (2009) Associação entre arquitetura de planta e produtividade de grãos em progênies de feijoeiro de porte ereto e prostrado. Pesquisa Agropecuária Brasileira, 44, 1647-1652. https://doi.org/10.1590/S0100-204X2009001200013

[11] Locatelli, V.E.R., Medeiro, R.D.S., Smiderle, O.J., Albuquerque, J.A.A.., Araújo, W.F. and Souza, K.T.S. (2014): Componentes de produção, produtividade e eficiência da irrigação do feijão-caupi no cerrado de Roraima. Revista Brasileira de Engenharia Agrícola e Ambiental, 18, 574-580. https://doi.org/10.1590/S1415-43662014000600002

[12] Andrade Jr., A.S., Rodrigues, B.H.N., Frizzone, J.A., Cardoso, M.J., Bastos, E.A. and Melo, F.B. (2002) Níveis de irrigação na cultura do feijão-caupi. Revista Brasileira de Engenharia Agrícola e Ambiental, 6, 17-20. https://doi.org/10.1590/s1415-43662002000100004

[13] Ferreira, V.M., Cardoso, M.J., Ribeiro, V.Q., Andrade Jr., A.S. and Morais, E.L.C. (2010) Performance produtiva do consórcio milho-feijão caupi e disponibilidade hídrica do solo. Revista Brasileira de Ciências Agrárias, 5, 177-186.

https://doi.org/10.5039/agraria.v5i2a405 
[14] Azevedo, B.M., Fernandes, C.N.V., Pinheiro, J.A., Braga, E.S., Campêlo, A.R., Viana, T.V.A., Camboim Neto, L.F. and Marinho, A.B. (2011) Efeitos de lâminas de irrigação na cultura do feijão vigna de cor preta. Agropecuária Técnica, 32, No. 1.

[15] Santos, C.A.F., Araújo, F.P. and Menezes, E.A. (2000) Comportamento produtivo de caupi em regimes irrigado e de sequeiro em Petrolina e Juazeiro. Pesquisa Agropecuária Brasileira, 35, 2229-2234. https://doi.org/10.1590/S0100-204X2000001100015

[16] Lopes, A.S., Oliveira, G.Q., Souto Filho, S.N., Goes, R.J. and Camacho, M.A. (2011) Manejo de irrigação e nitrogênio no feijoeiro comum cultivado em sistema de plantio direto. Revista Ciência Agronômica, 42, 51-56. https://doi.org/10.1590/S1806-66902011000100007

[17] Souza, L.S.B., Moura, M.S.B., Sediyama, G.C. and Silva, T.G.F. (2011) Eficiência do uso da água das culturas do milho e do feijão-caupi sob sistemas de plantio exclusivo e consorciado no semiárido brasileiro. Bragantia, 70, 715-721.

https://doi.org/10.1590/S0006-87052011000300030 